\title{
Hepatic estrogen and androgen receptors and binding proteins in streptozotocin-diabetic male Wistar rats
}

\author{
D. R.Smith, M.R. Rodway, W.A.Haniak and G.D.Bellward \\ Division of Pharmacology and Toxicology, Faculty of Pharmaceutical Sciences, University of British Columbia, Vancouver, Canada
}

\begin{abstract}
Summary. We have previously shown that there are decreases in the sex differences seen in certain hepatic drug and steroid metabolising enzymes in rats with early (4 day) streptozotocin-induced diabetes [31]. We postulated that hepatic sex hormone receptors or binding proteins might be involved in modulation of the sex differences noted in metabolism. In the present study, we measured the binding kinetics of the hepatic cytosolic estrogen receptor and androgen receptor, along with the high capacity-low affinity estrogen binding protein. At 4 or 10 days post-streptozotocin $(60 \mathrm{mg} / \mathrm{kg}$ intravenously), there was no change in the maximum binding capacity of the estrogen receptor, nor in the hormone affinity of any of the three proteins. However, the binding capacity of the androgen receptor and estrogen binding protein in the diabetic animals was decreased to less than half of control levels. This effect could not be reversed by hormone replacement with any of the following regimens: protamine zinc insulin, $10 \mathrm{U} / \mathrm{kg}$ subcutaneously once a day; Toronto insulin, $15 \mathrm{U} / \mathrm{kg}$ subcutaneously twice a day; testosterone enanthate, $1 \mathrm{mg} / \mathrm{kg}$ s. c. once a day; triiodothyronine, $30 \mu \mathrm{g} / \mathrm{kg}$ s.c. daily; ovine growth hormone: $0.02 \mathrm{U} / \mathrm{h}$ s.c., $30 \mu$ g s.c. 7 times
\end{abstract}

daily, $30 \mu \mathrm{g}$ i.v. 4 times daily; or various combinations of these hormones. Stress, such as 4 intravenous injections of saline per day, was noted to decrease the binding capacity of the estrogen binding protein. Therefore, we measured the basal serum corticosterone levels, which were not significantly different from control values in untreated or insulintreated diabetic rats. In addition, the hepatic cytosolic glucocorticoid receptor capacity was not significantly changed in the diabetic animals. This provides evidence that at 4 days post-streptozotocin, the diabetic state is not so stressful as to result in major alterations in these two parameters.

In summary, because insulin is known to restore the sex differences in hepatic drug and steroid metabolism to control levels but does not restore the capacity of the cytosolic androgen receptor or estrogen-binding protein, we conclude that they are not of primary importance in regulation of the metabolic enzymes.

Key words: Streptozotocin, diabetes, liver, estrogen receptor, androgen receptor, high capacity-low affinity estrogen binding protein.
The rate and route of catabolism of steroid hormones and many drugs are controlled by sex hormones and growth hormone in rat liver [1-4]. The effect of testosterone is well known and will not be discussed here. The interaction with growth hormone appears to involve androgenic stimulation of somatostatin release which, along with growth hormone releasing factor, modulates the release of growth hormone. This produces the sex differences seen in growth hormone patterns, i.e. the peak and trough ultradiene pattern of the male and the continuous presence of growth hormone in the plasma of the female [5-8]. These different patterns of growth hormone release result in differences seen in the metabolism of some steroids and drugs [9, 10].

The male rat liver contains several sex steroid binding proteins, the estrogen receptor [11-14], the high ca- pacity-low affinity estrogen binding protein (HCLA) [15-19], and the androgen receptor [20-22]. There is a sex difference only in the levels of the HCLA and androgen receptor [15, 18, 19, 21, 22]. Manipulations which abolish the hepatic sex differences in steroid and drug metabolism in adult rats, for example neonatal castration, hypophysectomy and gonadectomy, also abolish the sex differences seen in the levels of the androgen receptor or HCLA [18, 19, 23-27]. These observations led us to postulate that hepatic sex steroid binding proteins may be involved in modulation and control of the sex differences seen in metabolism.

It is of interest that in the diabetic state, there are also alterations in hepatic steroid and drug metabolism [27-31]. Many substrates which are normally metabolised faster in males than females, are decreased in catabolic rate by about $50 \%$ in the diabetic male rat 
liver [31]. In addition, diabetic male rats have decreased serum levels of testosterone and triiodothyronine, and a feminised pattern of growth hormone secretion [31-34]. Therefore, we formulated the hypothesis that some of the differences in hepatic steroid and drug catabolism known to occur in the diabetic state are mediated by changes in the capacity or affinity of the sex steroid binding proteins. To test this hypothesis, we examined streptozotocin-treated rats to determine the effects of diabetes on the hepatic cytosolic sex steroid binding proteins at a time point when alterations in metabolism are known to occur [31].

\section{Materials and methods}

\section{Chemicals and reagents}

Biofluor scintillation cocktail ; $\left[6,7-{ }^{3} \mathrm{H}(\mathrm{N})\right]$-estradiol, $40-60 \mathrm{Ci} / \mathrm{mmol}$; $\left[6.7-{ }^{3} \mathrm{H}(\mathrm{N})\right]$-dexamethasone $35-50 \mathrm{Ci} / \mathrm{mmol} ; 17-\alpha$ [methyl- $\left.{ }^{3} \mathrm{H}\right]$ methyltrienolone (R1881), 86-87 Ci/mmol; and R1881 were obtained from New England Nuclear (Boston, Mass, USA). [Monoethyl ${ }^{3} \mathrm{H}$ ] diethylstibesterol (DES) was purchased from Amersham (Oakville, Ont, Canada), dextran T-70 was obtained from Pharmacia Fine Chemicals AB (Uppsala, Sweden). Ammonium sulfate, ultrapure, was purchased from ICN Biomedical (Montreal, Quebec, Canada), and Alzet osmotic-minipumps, Model 2001 were obtained from Alza Corporation (Palo Alto, Calif, USA). Ovine growth hormone $(1.5 \mathrm{IU} / \mathrm{mg})$ was a gift of the National Institute of Diabetes, Digestive, and Kidney Diseases (Baltimore, Md, USA). Protamine zinc and Toronto insulin were products of Connaught Laboratories (Toronto, Ont, Canada), and Tes-Tape of Eli Lilly and Co. (Scarborough, Ont, Canada). Most other chemicals and hormones were obtained from Sigma Chemical Company (St. Louis, Mo, USA).

\section{Care and treatment of animals}

Male Wistar rats weighing 300-350 g, were obtained from Canadian Breeding Farms (Montreal, Quebec, Canada). Animals were housed in a separate animal room on Lobund bedding (Paxton Processing Ltd, Paxton, Ill, USA) under controlled light (0600 hours on, 2000 hours off) and temperature $\left(22^{\circ} \mathrm{C}\right)$. They were allowed free access to food (Purina Laboratory Chow, Ralston Purina of Canada Ltd, Woodstock, Ont, Canada) and tap water ad libitum. Rats were allowed a minimum of 3-4 days to equilibrate after shipment before starting treatment.

Streptozotocin was administered 4 or 10 days prior to animal use via a tail vein injection of $60 \mathrm{mg} / \mathrm{kg}$ in citrate buffer under light ether anaesthetic. Control animals were injected with vehicle only under similar conditions. Hormone replacement experiments were done using 4-day post-streptozotocin injected diabetic rats. All rats injected with streptozotocin had a glycosuria measurement of $0.5 \%$ or greater as determined by Tes-Tape, except those treated with insulin. The following hormones were injected subcutaneously once a day: protamine zinc insulin $(10 \mathrm{U} / \mathrm{kg})$, testosterone enanthate $(1 \mathrm{mg} / \mathrm{kg}$ in corn oil), triiodothyronine $\left(\mathrm{T}_{3} ; 30 \mu \mathrm{g} / \mathrm{kg}\right.$ in normal saline at $\left.\mathrm{pH} 8.5\right)$. Toronto insulin was administered subcutaneously twice a day $(15 \mathrm{U} /$ $\mathrm{kg})$. Ovine growth hormone $(\mathrm{oGH})$ was dissolved in normal saline $(\mathrm{pH}=8.5)$. It was either administered in a dose of $30 \mu \mathrm{g} / \mathrm{s}$. c. injection seven times per day at $0615,1015,1415,1815,2100,2340$, and 0240 hours or by continuous infusion of ovine growth hormone $0.02 \mathrm{U} / \mathrm{h}$, via Alzet Model 2001 minipumps implanted subcutaneously in the rostral half of ether-anaesthetized rats. For i.v. injection oGH was administered via the tail vein in conscious animals 4 times per day $(0900,1300,1700,2100$ hours $)$ in a dose of $30 \mu \mathrm{g} /$ injection.
Assays

a) Sex hormone receptors. Cytosol was prepared according to the method of Sunahara et al. [22] with the following modifications. The $105,000 \mathrm{~g}$ centrifugation for the estrogen receptor and HCLA was for $30 \mathrm{~min}$. An equal volume of saturated ammonium sulfate solution in buffer 1 was added dropwise over $30 \mathrm{~min}$ to the androgen receptor and estrogen receptor cytosolic fraction which was stirred on ice. This was centrifuged at $12,000 \mathrm{~g}$ for $30 \mathrm{~min}$. The resulting pellet was resuspended with buffer 1 to the original volume of cytosol (see " $d$ " below). The cytosols, protein concentration 1-3 $\mathrm{mg} / \mathrm{ml}$, were assayed for the androgen receptor (ligand $-^{3}[\mathrm{H}]-$ methyltrienolone, $0.05-5 \mathrm{nmol} / \mathrm{l}$ ) and HCLA (ligand- ${ }^{3}[\mathrm{H}]$-estradiol, 10-200 nmol/l) according to the method of Sunahara et al. [22]. The addition of 100-fold molar excess of triamcinolone acetonide was used to mask any glucocorticoid receptor interference with the androgen receptor assay. Higher concentrations of triamcinolone did not result in any change in capacity, and therefore were not necessary: binding capacity $\mathrm{fmol} / \mathrm{mg} \pm \mathrm{SEM}$ at 100 -fold excess $=20.76 \pm 1.49,500$-fold $=$ $16.65 \pm 6.91,1000$-fold $=19.08, n=5-43$. The estrogen receptor was assayed in a similar manner with $\left[{ }^{3} \mathrm{H}\right]$-DES as the ligand, final concentration $0.1-2.0 \mathrm{nmol} / \mathrm{l}$, and a 100-fold molar excess nonlabelled DES as the competitor. The incubation was for $1.5 \mathrm{~h}$, and $0.5 \%$ dextran-coated charcoal ( $0.5 \%$ charcoal, $0.05 \%$ dextran) was used to treat the mixture at the end of the incubation. Measurement of radioactivity and analysis of data were carried out as described by Sunahara et al. [22] using Scatchard analysis [31], resulting in values for the affinity $\left(\mathrm{K}_{\mathrm{d}}\right)$ and binding capacity $\left(\mathrm{B}_{\max }\right)$. Protein concentrations were determined by the method of Bradford [36]. In all cases, control experiments were carried out to ensure that equilibrium conditions were attained, and that saturation was achieved. In addition, control samples were assayed in parallel each day that experimental groups were assayed in order to check that vehicle treatment did not affect the results.

b) Serum corticosterone. Each animal was decapitated at 0800 hours in a quiet room, separate from all other animals. Serum was frozen and assayed for total corticosterone by the method of Kaneko et al. [37].

c) Glucocorticoid receptor. The hepatic glucocorticoid receptor was measured according to the methods of Beato and Feigelson [38] and Rosner and Polimeni [39]. Cytosol was prepared using buffer 2 .

d) Buffers. Buffer 1: $0.05 \mathrm{~mol} / 1$ tris-base; $1.5 \mathrm{mmol} / 1$ ethylenediamine tetraacetic acid disodium; $0.5 \mathrm{mmol} / 1$ dithiothreitol; $10 \%$ glycerol; $20 \mathrm{mmol} / 1$ sodium molybdate (for androgen receptor). Buffer 2: $10 \mathrm{mmol} / 1$ tris-base; $2.5 \mathrm{mmol} / 1$ ethylenediamine tetraacetic acid disodium ; $5 \mathrm{mmol} / 1$ dithiothreitol; $10 \%$ glycerol; $20 \mathrm{mmol} / 1 \mathrm{so}-$ dium molybdate (for glucocorticoid receptor).

\section{Statistical analysis}

Data were analysed using ANOVA and the Newman-Kuells multiple range test. Differences were considered significant from control at $p<0.05$. All samples were assayed in duplicate or triplicate.

\section{Results}

\section{The effect of streptozotocin-induced diabetes on hepatic cytosolic estrogen receptor, androgen receptor, and $H C L A$}

At 4 days post-induction of diabetes by streptozotocin there was no effect on the binding capacity or $K_{d}$ of the estrogen receptor (Table 1). A similar result was obtained after 10 days (data not shown). However, the 

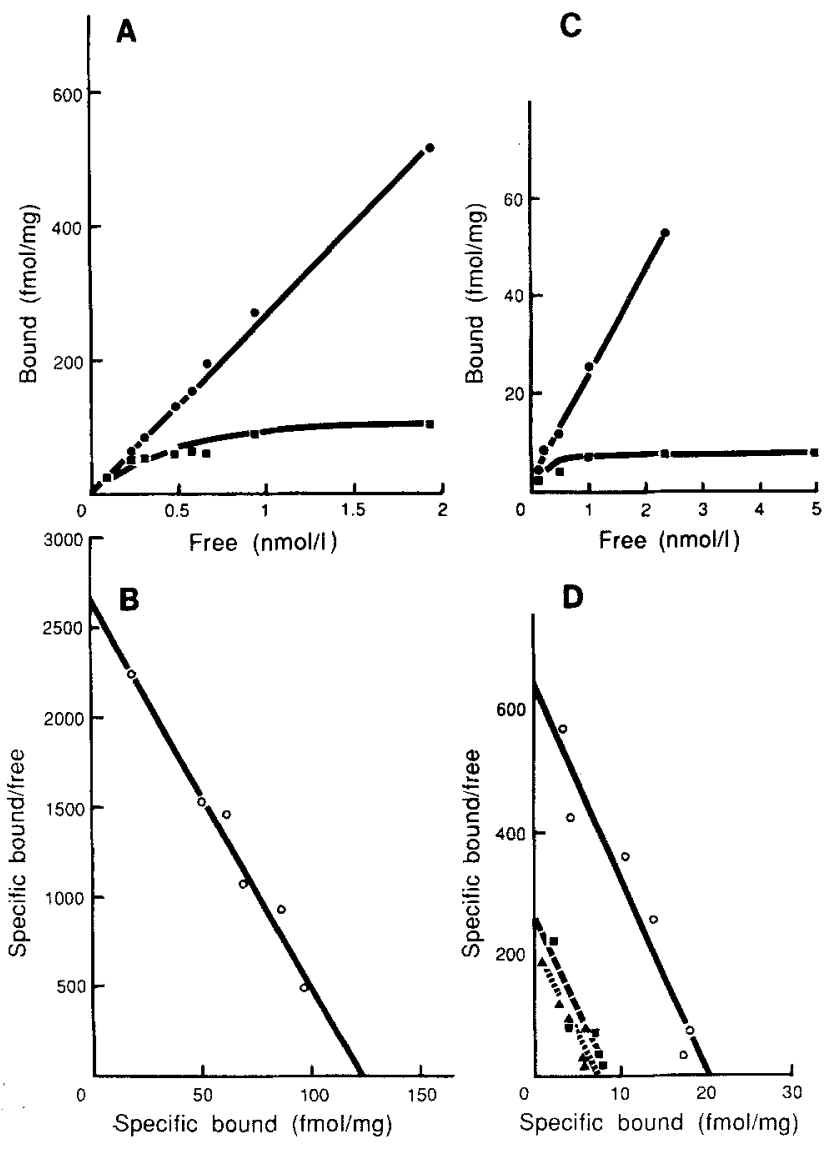

Table 1. Effects of 4-day streptozotocin (STZ) diabetes, with and without insulin treatment, on the rat hepatic estrogen receptor (ER). Protamine zinc insulin (PZI) dose: $10 \mathrm{U} / \mathrm{kg}$ s. c. for 4 days. Values are mean \pm SEM

\begin{tabular}{llll}
\hline Animal model & \multicolumn{2}{l}{ ER binding kinetics } \\
\cline { 2 - 4 } & $\mathrm{K}_{\mathrm{d}}(\mathrm{nmol} / \mathrm{l})$ & $\mathrm{B}_{\max }(\mathrm{fmol} / \mathrm{mg})$ & Number \\
\hline Control & $0.68 \pm 0.07$ & $121.1 \pm 6.25$ & 9 \\
4-day STZ & $0.83 \pm 0.36$ & $139.0 \pm 12.4$ & 4 \\
4-day STZ+PZI & $0.74 \pm 0.23$ & $217.0 \pm 23.8^{\mathrm{a}}$ & 4 \\
\hline
\end{tabular}

a Statistically different from control at $p<0.05$ level

HCLA and androgen receptor exhibited a greater than $50 \%$ decrease in binding capacity with no alterations in the $\mathrm{K}_{d}$ values at both 4 and 10 days of diabetes (Fig. 1, Table 2). The decrease in binding capacities was evident whether the results were calculated per $\mathrm{mg}$ protein as in Table 2, or per gram wet weight of liver (androgen receptor: control $=2.5 \pm 0.38$, 4-day streptozotocin $=0.94 \pm 0.23$, 10-day streptozotocin $=0.73 \pm 0.1$ $\mathrm{fmol} / \mathrm{g}$; HCLA: control = 5.18 \pm 1.12 , 4-day streptozotocin $=1.23 \pm 0.28,10$-day streptozotocin $=1.41 \pm$ $0.41 \mathrm{pmol} / \mathrm{g}$ ).

Further evidence that there were no changes in the affinity of steroid binding by receptors was obtained using competitor studies. For example, concentrations of unlabelled androgenic competitor of $0.1 \mathrm{pmol} / 1$ to $1 \mu \mathrm{mol} / 1$ were used to generate complete competition
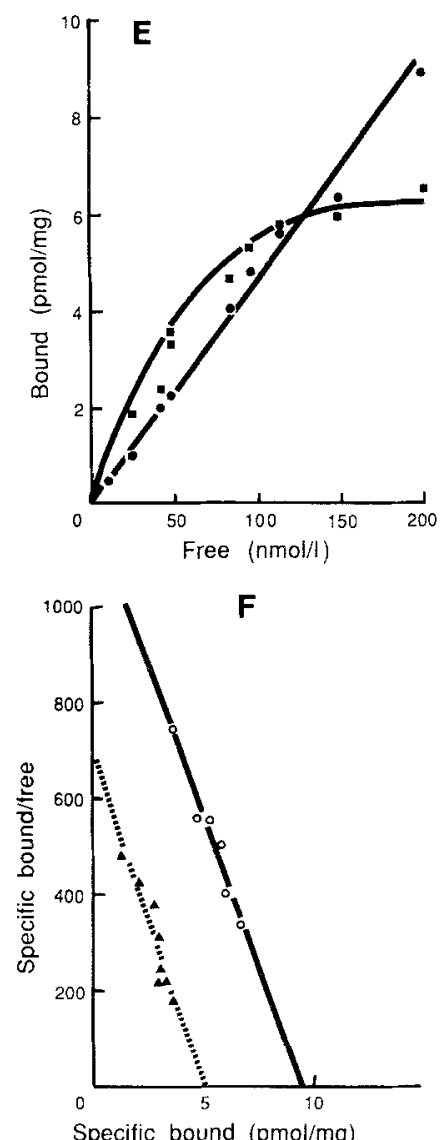

Fig. 1A-F. Examples of saturation curves and Scatchard plots of rat hepatic cytosolic estrogen $(\mathbf{A}, \mathbf{B})$ and androgen receptor $(C, D)$ and high capacity-low affinity estrogen binding protein (HCLA; E, F).

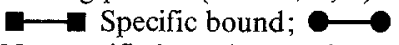
Nonspecific bound; $\mathrm{O}-\mathrm{O}$ Control animals; $-\rightarrow 4$ day diabetic rats; $\Delta$ III 10 day diabetic rats

curves for the androgen receptor. The competitor concentrations at which $50 \%$ of the radioactive ligand was displaced $\left(\mathrm{IC}_{50}\right)$ were calculated. The synthetic androgen, R1881, had the lowest $\mathrm{IC}_{50}$ (i.e. the highest affinity for the androgen receptor) with similar values in both control and 10-day diabetic rats; $5 \alpha$-dihydrotestosterone ranked next. No specific displacement occurred with $5 \beta$-dihydrotestosterone in either case. Testosterone and $17 \beta$-estradiol required concentrations several orders of magnitude higher in order to reach the $\mathrm{IC}_{50}$, both in control and 10-day diabetic animals.

Diabetes was confirmed by the presence of glyosuria of $0.5 \%$ or greater. Administration of insulin to the diabetic animals in doses which were able to prevent glycosuria was unable to restore the decreased binding capacity of the androgen receptor and HCLA (Table 2). There were no differences in the binding capacities between 4 and 10 days post-induction of diabetes. Since insulin-reversible changes in hepatic drug and steroid metabolism are observed at 4 days of diabetes [31], we conducted the rest of the experiments at this time.

\section{The effect of hormonal replacement in the 4-day diabetic animals}

Testosterone replacement to the diabetic animal did not result in restoration of the control androgen receptor or HCLA levels (Table 2). This treatment regimen 
Table 2. Effects of streptozotocin (STZ) diabetes, and various hormonal treatments on the rat hepatic androgen receptor and high capacitylow affinity estrogen binding protein: mean \pm SEM. PZI - protamine zinc insulin; ToI - Toronto insulin; TES - testosterone enanthate; oGH ovine growth hormone

\begin{tabular}{|c|c|c|c|c|c|c|}
\hline \multirow[t]{2}{*}{ Animal model } & \multicolumn{3}{|c|}{ Androgen receptor } & \multicolumn{3}{|c|}{ High capacity-low affinity estrogen binding protein } \\
\hline & $\mathrm{K}_{\mathrm{d}}(\mathrm{nmol} / \mathrm{l})$ & $\mathbf{B}_{\max }(\mathrm{fmol} / \mathrm{mg})$ & Number & $\mathrm{K}_{\mathrm{d}}\left(\times 10^{-7} \mathrm{~mol} / \mathrm{l}\right)$ & $\mathrm{B}_{\max }(\mathrm{pmol} / \mathrm{mg})$ & Number \\
\hline Vehicle control & $0.33 \pm 0.04$ & $22.51 \pm 2.48$ & 26 & $1.08 \pm 0.34$ & $14.83 \pm 3.97$ & 11 \\
\hline 4-day STZ & $0.31 \pm 0.05$ & $9.71 \pm 1.22^{\mathrm{a}}$ & 22 & $0.82 \pm 0.18$ & $4.82 \pm 0.95^{\mathrm{a}}$ & 8 \\
\hline 4-day STZ+PZI & $0.60 \pm 0.19$ & $11.56 \pm 3.72^{\mathrm{a}}$ & 4 & $0.79 \pm 0.19$ & $3.41 \pm 0.99^{\mathrm{a}}$ & 5 \\
\hline 4-day STZ+ToI & $0.28 \pm 0.06$ & $6.66 \pm 1.30^{\mathrm{a}}$ & 8 & $0.57 \pm 0.06$ & $1.41 \pm 0.38^{\mathrm{a}}$ & 7 \\
\hline 10-day STZ & $0.36 \pm 0.04$ & $8.31 \pm 1.21^{\mathrm{a}}$ & 23 & $0.51 \pm 0.26$ & $4.37 \pm 1.59^{\mathrm{a}}$ & 5 \\
\hline 10-day STZ+PZI & n.d. & n.d. & & $1.08 \pm 0.18$ & $5.72 \pm 1.23^{\mathrm{a}}$ & 5 \\
\hline 4-day STZ+TES & $0.41 \pm 0.07$ & $10.05 \pm 1.79^{\mathrm{a}}$ & 8 & $0.56 \pm 0.10$ & $3.65 \pm 0.82^{\mathrm{a}}$ & 5 \\
\hline 4-day $\mathrm{STZ}+\mathrm{T}_{3}$ & $0.12 \pm 0.01$ & $9.49 \pm 1.97^{\mathrm{a}}$ & 6 & $0.40 \pm 0.10$ & $1.83 \pm 0.40^{\mathrm{a}}$ & 5 \\
\hline 4-day STZ + oGH (mp) & $0.35 \pm 0.11$ & $7.16 \pm 1.92^{\mathrm{a}}$ & 6 & $0.56 \pm 0.11$ & $1.81 \pm 0.22^{\mathrm{a}}$ & 5 \\
\hline 4-day STZ + oGH (sc) & $0.33 \pm 0.11$ & $7.28 \pm 2.88^{\mathrm{a}}$ & 7 & $0.52 \pm 0.06$ & $1.54 \pm 0.28^{\mathrm{a}}$ & 7 \\
\hline Vehicle control ${ }^{c}$ & $0.25 \pm 0.03$ & $20.98 \pm 3.20$ & 8 & $0.66 \pm 0.11$ & $4.05 \pm 0.47^{\mathrm{a}}$ & 4 \\
\hline Vehicle + 4-day STZ & $0.33 \pm 0.06$ & $7.75 \pm 0.75^{b}$ & 6 & $0.36 \pm 0.03$ & $2.07 \pm 0.37^{\mathrm{b}}$ & 4 \\
\hline 4-day $\mathrm{STZ}+\mathrm{oGH}^{\mathrm{c}}$ & $0.44 \pm 0.18$ & $5.41 \pm 1.93^{b}$ & 4 & $0.43 \pm 0.04$ & $2.25 \pm 0.34^{b}$ & 4 \\
\hline $\begin{array}{l}\text { 4-day STZ+oGH } \\
+ \text { TES + PZIc }\end{array}$ & $0.15 \pm 0.06$ & $10.12 \pm 1.02^{b}$ & 4 & $0.54 \pm 0.18$ & $2.37 \pm 0.37^{b}$ & 4 \\
\hline
\end{tabular}

n.d., Not determined; $\mathrm{mp}=$ osmotic minipump; $\mathrm{sc}=$ subcutaneous injection. a Different from control at $p<0.05 ;{ }^{\mathrm{b}}$ different from control and vehicle injected control at $p<0.05 ;{ }^{\mathrm{c}}$ four daily intravenous injections of either saline or oGH

Table 3. Effects of streptozotocin (STZ) diabetes, with and without insulin therapy, on serum corticosterone levels and hepatic glucocorticoid receptor (GR) in male Wistar rats. Values are the mean \pm $\mathrm{SEM} ; \mathrm{PZI}=$ protamine zinc insulin $(10 \mu / \mathrm{kg}$ s.c. once per day)

\begin{tabular}{|c|c|c|c|c|c|}
\hline \multirow{2}{*}{$\begin{array}{l}\text { Animal } \\
\text { model }\end{array}$} & \multirow{2}{*}{$\begin{array}{l}\text { Serum } \\
\text { cortico- } \\
\text { sterone } \\
(\mu \mathrm{g} / 100 \mathrm{ml})\end{array}$} & \multirow{2}{*}{$\begin{array}{l}\text { Num- } \\
\text { ber }\end{array}$} & \multicolumn{2}{|c|}{ GR binding kinetics } & \multirow{2}{*}{$\begin{array}{l}\text { Num- } \\
\text { ber }\end{array}$} \\
\hline & & & $\begin{array}{l}\mathrm{K}_{\mathrm{d}} \\
(\mathrm{nmol} / \mathrm{l})\end{array}$ & $\begin{array}{l}\mathrm{B}_{\max } \\
(\mathrm{fmol} / \mathrm{mg} \\
\text { protein) }\end{array}$ & \\
\hline Control & $2.65 \pm 0.85$ & 4 & $1.40 \pm 0.31$ & $88.2 \pm 15.3$ & 6 \\
\hline 4-day STZ & $3.95 \pm 1.39$ & 4 & $1.92 \pm 0.59$ & $114.3 \pm 31.1$ & 8 \\
\hline $\begin{array}{l}\text { 4-day STZ } \\
+ \text { PZI }\end{array}$ & $2.06 \pm 0.52$ & 4 & $1.57 \pm 0.49$ & $107.9 \pm 15.6$ & 6 \\
\hline
\end{tabular}

had previously been shown to restore serum testosterone levels to normal and to reverse the alterations in drug and steroid metabolism [22]. Treatment with triiodothyronine was also ineffective in increasing the binding proteins to normal. Ovine growth hormone was administered in doses calculated to restore the normal male release pattern ( 7 s.c. doses per day). Also, we administered intravenous tail vein injections 4 times a day at a dose of $30 \mu \mathrm{g} /$ injection. This dosage regimen has been shown to restore drug and steroid metabolism to normal [40]. However, all growth hormone regimens were ineffective in restoring the hormone binding protein levels. Addition of protamine zinc insulin and testosterone to the treatment regimen to more closely duplicate the normal physiological situation was also ineffective in restoring the HCLA and androgen receptor levels.

\section{Serum corticosterone and glucocorticoid receptor levels}

Stress appeared to have an effect on the HCLA binding proteins; decreased levels were noted in the ani- mals subjected to 4 daily intravenous injections, including the control group. Therefore, we measured the levels of serum corticosterone and hepatic glucocorticoid receptor to determine if changes in these parameters could be complicating our analyses (Table 3 ). There were no significant differences among the three experimental groups-control, 4-day diabetic and insulin-treated diabetic animals, with regard to the serum corticosterone levels or binding capacity of the glucocorticoid receptor. Therefore, there is no evidence that these animals were under any significant stress, e.g. due to the diabetic state itself.

\section{Discussion}

We found no alterations in the kinetics of the male hepatic estrogen receptor with short term (4-10 days) streptozotocin diabetes. Our results are in accord with those of Ekka et al. [41, 42] who used Scatchard analysis to compare the number of uterine estrogen receptor binding sites between control and diabetic female rats; they found no differences. There was a slight increase in estrogen receptor binding capacity in the diabetic male treated with insulin in our study. This may be due to a stabilising effect of insulin upon the hepatic estrogen receptor [43].

In contrast to the lack of effect on the estrogen receptor, we found a significant decrease in the binding capacity of both the androgen receptor and HCLA 4 days after streptozotocin-induction of diabetes. The decrease seen in the male hepatic androgen receptor and HCLA was of a similar magnitude to the decrease reported for the prostatic androgen receptor in streptozotocin-diabetic male rats [44]. However, unlike the 
prostatic androgen receptor, neither testosterone nor insulin treatments were able to restore the hepatic androgen receptor or HCLA. This is in contrast to what occurs with drug and steroid metabolism. We have consistently found that control levels of metabolism are restored with treatments equal in dosage and time length to those which were used in Table $2[1,31]$. Since insulin also prevents a generalised decrease in hepatic protein concentration which can occur in diabetic rats $[45,46]$, the reduction in binding capacities does not appear to be a generalised effect.

When given in the male release pattern, the ineffectiveness of ovine growth hormone in restoring the reduced binding capacities of the androgen receptor and HCLA indicates that the presence of peaks of growth hormone in the blood is not the regulatory factor in the androgen receptor and HCLA levels. Possibly the inability of the present study to obtain sufficiently lowtrough plasma levels between the peaks was a factor in this lack of response. None of the treatment regimens attempted was able to restore the proteins to their control levels even when the hormones were combined. No evidence for a change in affinity of binding of steroids to the various proteins was noted. In fact, the $\mathrm{IC}_{50}$ values were quite similar between control and diabetic-derived fractions using a number of steroid competitors.

Basal serum corticosterone levels remained normal in both the untreated and insulin-treated diabetic animals. Also, hepatic glucocorticoid receptor capacity was not significantly changed by diabetes. Svec reported similar results with respect to the hepatic glucocorticoid receptor in 4-day streptozotocin-diabetic rats [47]. We conclude from this that the diabetic state was not excessively stressful with regard to the parameters measured.

Analysis of the nuclear receptor levels is now being carried out. These values together with the present study may provide more complete data with regard to the effects of diabetes on hormone receptors in the liver.

In conclusion, we found that 4 or 10 days' duration of streptozotocin-induced diabetes in the male Wistar rat did not affect the capacity or affinity of binding of the hepatic cytosolic-estrogen receptors. No change in binding affinity occurred in either the androgen receptor or high capacity-low affinity estrogen binding protein. However, the capacities of both these proteins were reduced to less than half of control values in the diabetic state. Hormone treatments which are known to correct diabetic-induced alterations in hepatic drug and steroid metabolism were ineffective in restoring the decreased binding capacities of the androgen receptor and estrogen binding protein. Therefore, it is concluded that these cytosolic proteins do not play a direct role in the regulation of drug and steroid metabolism in the diabetic rat.
Acknowledgement. Supported by the Medical Research Council of Canada, Grant MA-5944.

\section{References}

1. Bellward GD, Pak RCK, Gontovnick LS, Warren BL, Finlayson MJP, Sunahara GI (1982) Endogenous mechanisms for the regulation of hepatic microsomal drug and steroid mixed function oxidases. In: Stich HF, Leung HW, Roberts JR (eds) Workshop on the Combined Effects of Xenobiotics. National Research Council of Canada, Publication Number 18978: 97-126

2. Gustafsson JA, Mode A, Norstedt G, Skett P (1983) Sex steroid induced changes in hepatic enzymes. Ann Rev Physiol 45: 51-60

3. Colby HD (1980) Regulation of hepatic drug and steroid metabolism by androgens and estrogens. In: Thomas JA, Singhad RL (eds) Advances in Sex Hormone Research, Vol 4. Urban and Schwarzenberg, München Wien Baltimore, pp 27-71

4. Finnen MJ, Hassall KA (1984) Effect of hypophysectomy on sex differences in the induction and depression of hepatic drug metabolizing enzymes in the rat. J Pharmacol Exp Ther 229: 250-254

5. Tannenbaum GS (1981) Growth hormone secretory dynamics in streptozotocin diabetes: evidence of a role for endogenous circulating somatostatin. Endocrinology 108: 76-82

6. Tannenbaum GS, Ling N (1984) The interrelationship of growth hormone $(\mathrm{GH})$-releasing factor and somatostatin in generation of the ultradiene rhythm of GH secretion. Endocrinology 115: 952-958

7. Tannenbaum GS, Martin JB (1976) Evidence for an endogenous ultradiene rhythm governing growth hormone secretion in the rat. Endocrinology $98: 562-570$

8. Eden S (1979) Age and sex-related differences in episodic growth hormone secretion in the rat. Endocrinology 105: 555-560

9. Gustafsson JA, Eden S, Eneroth P, Hokfelt TR, Isaksson O, Jansson JO, Mode A, Norstedt G (1983) Regulation of sexually dimorphic hepatic steroid metabolism by the somatostatin-growth hormone axis. J Steroid Biochem 19: 691-698

10. Virgo BB (1985) Effects of somatostatin and testosterone on the hepatic monooxygenase system in castrated male rats. Drug Metab Dispos 13: 9-13

11. Eisenfeld AJ, Aten R, Weinberger M, Haselbacher G, Halpern $K$, Krakoff L (1976) Estrogen receptor in the mammalian liver. Science 191: 862-865

12. Eisenfeld AJ, Aten RF, Haselbacher GK, Halpern K (1977) Specific macromolecular binding of estradiol in the mammalian liver supernatant. Biochem Pharmacol 26: 919-922

13. Viladiu P, Delgado C, Pensky J, Pearson OH (1975) Estrogen binding protein of rat liver. Endocr Res Commun 2: 273-280

14. Chamness GC, Costlow ME, McGuire WL (1975) Estrogen receptor in rat liver and its dependence on prolactin. Steroids 26 : 363-371

15. Dickson RB, Aten RF, Eisenfeld AJ (1978) An unusual sex steroid binding protein in mature male rat liver cytosol. Endocrinology 203: 1636-1646

16. Singletary BK, Zdunek JR, van Theil DH, Eagon PK (1982) Estrogen binding protein in male rat liver and other tissues. Horm Res 16: 377-384

17. Powell-Jones W, Thompson C, Nayfeh SN, Lucier GW (1980) Sex differences in estrogen binding by cytosolic and nuclear components of rat liver. J Steroid Biochem 13: 219-229

18. Eagon PK, Fischer SE, Imhoff AF, Porter LE, Stewart RR, van Thiel DH, Lester R (1980) Estrogen binding proteins of male rat liver: influences of hormonal changes. Arch Biochem Biophys 201: 486-499

19. Thompson C, Powell-Jones W, Lucier GW (1981) Sex differences in hepatic estrogen binding proteins. Biochem J 194: 1-8

20. Roy AK, Milin BS, McMinn DA (1974) Androgen receptor in rat liver: hormonal and developmental regulation of the cytoplasmic receptor and its correlation with androgen-dependent synthesis 
of alpha-2mu-globulin $(\alpha-2 \mu)$. Biochem Biophys Acta 354: 213-232

21. Levinson DJ, Decker DE (1985) Characterization of a $\left[{ }^{3} \mathrm{H}\right] \mathrm{meth}-$ yltrienolone (R1881) binding protein in rat liver cytosol. J Steroid Biochem 22: 211-219

22. Sunahara GI, Finlayson MJP, Warren BL, Bellward GD (1985) Characterization studies of a rat hepatic cytosolic androgenbinding protein. Can J Physiol Pharmacol 63: 952-957

23. Thompson C, Lucier GW (1983) Hepatic estrogen responsiveness: possible mechanisms for sexual dimorphism. Mol Pharmacol 24: 69-76

24. Powell-Jones W, Thompson G, Raeford S, Lucier GW (1981) Effect of gonadectomy on the ontogeny of estrogen-binding components in rat liver cytosol. Endocrinology 109: 628-636

25. Rumbaugh RC, Clark JC, McDaniels OS, Lucier GW (1983) Feminization of the concentrations of hepatic estrogen-binding proteins by ectopic pituitary. Endocrinology 112: 1363-1369

26. Turocy JF, Chiang AN, Seeley DH, Eagon PK (1985) Effects of $\mathrm{H}_{2}$-antagonists on androgen imprinting of male hepatic function. Endocrinology 117: 1953-1961

27. Reinke LA, Stohs SJ, Rosenberg H (1978) Altered activity of hepatic mixed function monooxygenase enzymes in streptozotocin induced diabetic rats. Xenobiotica 8: 611-619

28. Reinke LA, Stohs SJ, Rosenberg H (1979) Increased aryl hydrocarbon hydroxylase activity in hepatic microsomes from streptozotocin-diabetic female rats. Xenobiotica 8: 769-778

29. Stohs SJ, Reinke LA, Hassing JM, Rosenberg H (1979) Benzo[a]pyrene metabolism by hepatic and extrahepatic tissues in streptozotocin-diabetic rats. Drug Metab Dispos 7: 49-51

30. Peng R, Tennant P, Lorr NA, Yang CS (1983) Alterations of microsomal monooxygenase system and carcinogen metabolism by streptozotocin induced diabetes in rats. Carcinogenesis 4: 703-708

31. Warren BL, Pak R, Finlayson M, Gontovnick L, Sunahara G, Bellward GD (1983) Differential effects of diabetes on microsomal metabolism of various substrates: comparison of streptozotocin and spontaneously diabetic Wistar rats. Biochem Pharmacol 32: 327-335

32. Tesone M, Biella de Souza Valle L, Fogalia VG, Charreau EH (1976) Endocrine function of the testis in streptozotocin diabetic rats. Acta Physiol Lat Am 26: 387-394

33. Mitsuma T, Nogimori T (1982) Effects of streptozotocin induced diabetes mellitus on hypothalamic-pituitary-thyroid axis in rats. Endocrinol Jpn 29: 695-700

34. Ortiz-Caro J, Gonzalez G, Jolin T (1984) Diurnal variations of plasma growth hormone, thyrotropin, thyroxine, and triiodothyronine in streptozotocin-diabetic and food restricted rats. Endocrinology 115: 2227-2232
35. Scatchard G (1949) The attraction of proteins for small molecules and ions. Ann NY Acad Sci 51: 660-672

36. Bradford MM (1976) A rapid and sensitive method for the quantification of microgram quantities of protein utilizing the principle of protein-dye binding. Anal Biochem 72: 248-254

37. Kaneko M, Kaneko M, Shinsako J, Dallman MF (1981) Adrenal sensitivity to adrenocorticotropin varies diurnally. Endocrinology 109: $70-75$

38. Beato M, Feigelson P (1972) Glucocorticoid-binding proteins of rat liver cytosol. I. Separation and identification of the binding proteins. J Biol Chem 247: 7890-7896

39. Rosner W, Polimeni ST (1978) An exchange assay for the cytoplasmic glucocorticoid receptor in the liver of the rat. Steroids 31: 427-438

40. Skett P, Young C (1982) The effects of pituitary hormones on hepatic drug metabolism in the rat. Acta Endocrinol 100: 421-426

41. Ekka E, Vanderheyden I, DeHertogh R (1982) Short term nuclear retention in uteri of ovariectomized diabetic rats after intraperitoneal injection of $17 \beta$-estradiol: evidence for decreased hormonal activity on protein synthesis. Endocrinology 111: 456-460

42. Ekka E, Vanderheyden I, DeHertogh R (1981) Oestrogen receptors and estrogen-induced protein synthesis in the uterus of diabetic rats. Diabetologia 20: $578-582$

43. Lui YY, Thompson CL, Powell-Jones W, McDaniels OS, Lucier GW (1984) Cytosolic and nuclear estrogen receptors in the isolated perfused rat liver. J Pharmacol Exp Ther 229: 474-480

44. Tesone M, Oliveira-Filho RM, Biella de Souza Valle L, Calvo JC, Baranao JLS, Foglia VC, Charreau EH (1980) Androgen receptors in the diabetic rat. Diabetologia 18: $385-390$

45. McNurlan MA, Garlick PJ (1979) Rates of protein synthesis in rat liver and small intestine in protein deprivation and diabetes. Proc Nutr Soc 38: 133A

46. Albertse EC, Garlick PJ, Pain VM (1980) The effect of streptozotocin diabetes on liver protein metabolism. Proc Nutr Soc 39: $50 \mathrm{~A}$

47. Svec F (1985) Glucocorticoid receptor number in ob/ob mice and streptozotocin-treated rats. Horm Metab Res 17: 396-398

Received: 15 July 1987

and in revised form: 20 October 1987

Dr. G.D. Bellward

Division of Pharmacology and Toxicology

Faculty of Pharmaceutical Sciences

2146 East Mall

Vancouver, B.C. V6T 1W5

Canada 